\title{
KEMUDAHAN DAN KEMANFAATAN PENGARUHNYA TERHADAP KEPUTUSAN PENGGUNAAN SISTEM PEMBAYARAN E-MONEY OVO, GO-PAY, DAN DANA
}

\author{
${ }^{1}$ Rizki Aprilia Dwi Susanti, ${ }^{2}$ Dewi Fardahlia, ${ }^{3}$ Poppy Indrihastuti \\ Universitas Tribhuwana Tunggadewi Malang \\ E-mail:Rizkiunitri2@gmail.com
}

\begin{abstract}
The results of this study use quantitative research. Data were collected using a questionnaire of 90 respondents and the population in this study were management students at the University of Tribhuwana Tunggadewi Malang with the research sample used was purposive sampling. Data were analyzed using multiple linear regression analysis with the result that the effect of convenience partially had a significant effect on the electronic money payment system with a value of $t$ arithmetic $>t$ table and a significant value <0.05. The effect of partial benefit has a significant influence on the electronic money payment system with a value of t arithmetic $>$ T table and a significant value <0.05. While simultaneously the effect of convenience, and expediency has a significant effect on the electronic money payment system by producing a significant probability value $<0.05$, simultaneously the ease and benefit variable has a significant effect on the electronic money payment system with case studies of ovo, go-pay users and funds to management students at the Malang Tribhuwana Tunggadewi University.
\end{abstract}

Keywords: Ease, Benefits and Electronic Payment Systems.

\begin{abstract}
Abstrak
Hasil pada penelitian ini menggunakan jenis penelitian kuantitatif. Data dikumpulkan dengan menggunakan kuesioner sebanyak 90 responden dan yang menjadi populasi dalam penelitian ini adalah mahasiswa manajemen di Universitas Tribhuwana Tunggadewi Malang dengan sampel penelitian yang digunakan yaitu purposive sampling. Data dianalisiss menggunakan analisis regresi linier berganda dengan hasil bahwa pengaruh kemudahan secara parsial memiliki pengaruh yang signifikan terhadap system pembayaran elektronik money dengan nilai t hitung > t tabel dan nilai signifikan $<0,05$. Adapun pengaruh kemanfaatan secara parsial memiliki pengaruh yang signifikan terhadap sistem pembayaran elektronik money dengan nilai t hitung > t tabel dan nilai signifikan $<0,05$. Sedangkan secara simultan pengaruh kemudahan, dan kemanfaatan memiliki pengaruh yang signifakan terhadap sistem pembayaran elektronik money dengan menghasilkan nilai probabilitas signifikan $<0,05$ maka secara simultan variabel kemudahan dan kemanfaatan berpengaruh secara signifikan terhadap sistem pembayaran elektronik money dengan studi kasus pengguna ovo, go-pay dan dana pada mahasiswa manajemen di universitas tribhuwana tunggadewi malang.
\end{abstract}

Kata Kunci: Kemudahan, Kemanfaatan dan Sistem Pembayaran Elektronik Money. 


\section{PENDAHULUAN}

Perkembangan Financial yang semakin modern ini sangat banyak diminati oleh masyarakat sebagai penggunanya. Dunia setiap harinya selalu mengalami perkembangan yang sangat cepat, dalam dunia teknologi pada saat sekarang banyak mengalami sebuah persaingan yang semakin ketat sehingga masyarakat selalu mengikuti zaman tersebut. Pada zaman sekarang adalah zaman era modern, dimana semuanya serba canggih khususnya dalam hal teknologi. Masyarakat selalu mengikuti perkembangan zaman, karena tidak mau kalah dalam bersaing untuk kemudahan dalam menggunakan teknologi pada era modern, tidak hanya anak-anak, remaja, dewasa, bahkan orang tua pun juga menggunakan teknologi yang canggih. Semakin ketatnya persaingan masyarakat juga harus pintar dalam memilih teknologi yang saat ini sedang lagi mendunia dan kemudahan serta manfaatnya sangat cepat dijangkau.

Salah satu teknologi atau alat yang memudahkan dan sangat cepat penggunaannya yaitu E-Money, merupakan sebuah alat sistem pembayaran modern yang berbasis digital. Elecktronic Money (E-money) Pengertian E-Money berdasarkan Bank for Internasional Settlement (BIS,1996) yaitu "Stored-value or prepaid products in which a record of the funds or value available to a consumer is stored on an electronic devicein the consumer's possession" (Produk stored-value atau prepaid dimana sejumlah nilai uang disimpan dalam suatu media elektronis yang dimiliki seseorang) dalam (Hidayati 2006:4) Dengan adanya E-Money semua masyarakat bisa menggunakan untuk mengirim uang lewat elektronik tanpa harus pergi ke pos dan bank atau tempat lainnya. Penggunaan E-Money bisa mengurangi pertumbuhan masyarakat yang menggunakan uang tunai khususnya untuk pembayaran yang bersifat mikro sampai dengan ritel (Hidayati,2006:1). Ribuan masyarakat sekarang menggunakan alat tersebut sebagai alat pengiriman uang melalui elektronik, tidak hanya untuk mengirim uang saja, uang elektronik bisa juga berupa saldo yang dinamakan saldo OVO, GO-Pay dan Dana, saldo itu bisa digunakan untuk apapun yaitu membeli makan, baju, pesan transportasi, pengiriman barang, dan lain sebagainya.

E-Money adalah salah satu produk financial technology (fintech) yang bergerak pada bisnis start up di bidang sektor keuangan digital (Rifqi Tazkiyyaturrohmah:2018). Salah satu era mendunia sekarang penyedia jasa transportasi online yang dinamakan Grab dan Go-Jek merupakan salah satu alat transportasi yang paling banyak diminati publik karena menggunakan E-Money (Rizqi Tazkiyyaturrohmah: 2018), dalam transportasi tersebut Grab menggunkan saldo OVO dan Go-Jek menggunakan Go-Pay. Manfaat serta kemudahan yang ditawarkan uang elektronik pada produk Grab, Go-jek dan produk lainnya dapat mempengaruhi sistem pembayaran elektronik yang semakin meningkat. Ketika sebuah produk memiliki manfaat dan kemudahannya bisa digunakan dalam kehidupan sehari-hari, maka kemungkinan produk tersebut akan digunakan dan berkembang di masyarakat luas. Begitu pula dengan produk dari grab dan go-jek atau produk lainnya yang dirasa sangat membantu untuk kepentingan transaksi perekonomiannya, bukan tidak mungkin masyarakat akan berminat untuk menggunakan produk tersebut dalam sistem pembayarannya.

E-money ini tidak hanya di perusahaan bisnis start up atau transportasi online, penerbit $e$-money adalah Bank Indonesia, salah satu kartu elektronik berupa saldo yang jumlah pengisiannya lebih besar dinamakan Dana. Dana adalah suatu sumber yang 
digunakan untuk membiayai operasinya dan itu bisa diperoleh dari beberapa sumber dana seperti modal sendiri, pinjaman, maupun lembaga lainnya (Kasmir 2014: 58). Bahkan terdapat masyarakat yang mengira bahwa e-money merupakan produk pinjaman, dan transaksi menggunakan pulsa (Bhaskoro,2013). Penggunaa ragam alat pembayaran non-tunai juga dapat mencegah uang rusak atau basah (Adhinagari, 2018). Penerbit atau penyedia dari uang elektronik pun beragam seperti e-money yang merupakan produk dari Bank Mandiri, Brizzi, yang merupakan produk dari BCA, GoPay yang merupakan produk dari Go-Jek, Ovo yang merupakan produk dari Grab, dan produk Dana dll.

E-Money saat ini menjadi tren yang mendunia dan peminatnya ribuan masyarakat, terutama mahasiswa yang menyukai hal-hal modern dan serba canggih untuk menuntutnya memenuhi keinginan yang dibutuhkan. Pada dasarnya manusia adalah butuh dan ingin mensejahterakan hidupnya, secara umum sebuah kebutuhan disertai oleh perasaan tertentu atau emosi dan ia memiliki sebuah cara khusus mengekspresikan dirinya dalam mencapai resolusi (Murray, 1938: 123-125). Persaingan transportasi online antara Grab dan Go-Jek tidak hanya seputar bisnis jaringan saja, tetapi juga penggunaan $e$-money dalam sistem pembayarannya lebih murah dan mudah yang mana antara dua transportasi online tersebut (Rifqi Tazkiyyaturrohmah:2018)

Manfaat serta kemudahan yang ditawarkan uang elektronik pada produk Grab, Go-jek dan produk lainnya dapat mempengaruhi sistem pembayaran elektronik yang semakin meningkat. Ketika sebuah produk memiliki manfaat dan kemudahannya bisa digunakan dalam kehidupan sehari-hari, maka kemungkinan produk tersebut akan digunakan dan berkembang di masyarakat luas. Begitu pula dengan produk dari grab dan go-jek atau produk lainnya yang dirasa sangat membantu untuk kepentingan transaksi perekonomiannya, bukan tidak mungkin masyarakat akan berminat untuk menggunakan produk tersebut dalam sistem pembayarannya.

Pada penelitian ini adalah, objeknya yaitu mahasiswa prodi manjemen yang menggunakan E-Money dalam bentuk aplikasi transportasi online Grab (OVO) dan GoJek (Go-Pay dan layanan pengiriman uang dalam jumlah besar (Dana) yang berada di Universitas Tribhuwana Tunggadewi Malang. Hal terutama peneliti mengambil objek penelitian pada mahasiswa prodi manajemen di Universitas Tribhuwana Tunggadewi Malang yaitu mahasiswa era modern mayoritas sudah menggunakan alat telekomunikasi yang canggih, bahkan aplikasi game olnline, belanja online, transportasi online, semua sudah terdownload aplikasinya karena kemudahan teknologi yang canggih pada era modern ini. E-Money alat pembayaran non tunai ini sangat diminati oleh mahasiswa dikarenakan selain murah juga tidak menguras kantong mahasiswa, serta dapat memenuhi kebutuhan mahasiswa yang diinginkan.

\section{LANDASAN TEORI \\ Pengertian E-Money}

E-money atau uang elektronik adalah alat transaksi keuangan modern yang berbentuk pembayaran non tunai. Uang elektronik ini bisa digunakan untuk transaksi apapun, pembayaran transportasi online, belanja online, pembayaran toll dan lain sebagainya. Menurut Hidayati (2006:4) pengertian e-money mengacu pada definisi yang dikeluaran oleh Bank for International Settelment (BIS) dalam salah satu publikasiya 
pada bulan oktober 1996 mendefinisikan uang elektronik sebagai "stored value or prepaid products in which a record an electronik device in the consumer's possesion" (produk stored value atau prepaid dimana sejumlah uang disimpan dalam suatu media elektronis yang dimiliki seseorang).

Dalam peraturan pemerinta melalui bank indonesia telah menyempurnakan aturan uang elektronik melalui perubahan payung hukum dari PBI No. 11 12//PBI/2009 menjadi PBI No. 168//PBI/2014. Yang mana dalam peraturan tersebut BI melarang penerbit uang elektronik untuk menahan nilai minimum transaksi uang elektronik. Maka jika bank menentukan batas minimum yang harus ditahan oleh bank ketika menarik tabungan, maka uang elektronik bisa di ambil hingga saldonya nol. Uang elektronik berfungsi sama dengan uang tunai tetapi perbedannya hanya dari segi bentu saja. Karenanya harus dapat digunakan seluruhnya sampai saldonya nihil. Indikator sistem transaksi keuangan modern ini yaitu: (1) Pelayanan tercepat untuk masyarakat yang sangat membutuhkan dengan keadaan yang mendesak dan mudah dijangkau di luar kota juga; (2) Waktu yang digunakan lebih singkat, efektif, dan eisien; (3) Dapat diisi atau Top-up kapan saja dengan layanan yang tersedia.

\section{Pengertian Kemudahan}

Menurut Jogiyanto (2007:115), pengertian kemudahan penggunaan didefinisikan sebagai sejauh mana seseorang percaya bahwa menggunakan suatu sistem teknologi tertentu akan bebas dari suatu usaha. Masyarakat dalam hal ini sudah terbiasa hidup dengan gaya modern dan mengikuti perkembangan zaman, dimana lebih suka cara yang mudah aman dan pastinya relatif murah. Berdasarkan pengertian dari kemudahan dapat disimpulkan secara luas bahwa kemudahan ini adalah suatu kepercayaan tentang proses pengambilan keputusan. Apabila seseoran merasakan percaya bahwa sistem informasi dan teknolofi ini mudah digunakan, pasti seseorang akan menggunakannya. Begitu sebaliknya, apabila seseorang merasa percaya bahwa sistem teknologi tidak mudah digunakan, pasti seseorang tersebut tidak akan menggunakannya.

\section{Faktor-Faktor Yang Mempengaruhi Kemudahan}

Menurut Panggih Rizki Dwi Lestari (2014:19-20) kemudahan dalam menggunakan teknologi dipengaruhi beberapa faktor: (a) Faktor pertama berfokus pada teknologi itu sendiri, suatu teknologi yang baik dan digunakan secara terus menerus akan memberikan kemudahan bagi pengguna dalam menggunakannya. Contohnya pengalaman pengguna terhadap penggunaan teknologi sejenis akan memberikan kemudahan pengguna; (b) Faktor kedua adalah reputasi akan teknologi tersebut yang diperoleh oleh pengguna. Reputasi yang baik yang didengar oleh pengguna akan mendorong keyakinan engguna terhadap kemudahan penggunaan teknologi tersebut; dan (c) Faktor ketiga yang mempegaruhi persepsi pengguna terhadap kemudahan menggunakan teknologi adalah tersedianya mekanisme pendukungbyang handal. Mekanisme pendukung yang terpercaya akan membuat pengguna merasa nyaman dan merasa yakin, bahwa terdapat mekanisme pendukung yang hanadal jika terjadi kesulitan dalam menggunakan teknologi, aka mendorong persepsi pengguna ke arah yang lebih positif. 


\section{Indikator Kemudahan}

Menurut Davis (1989) dalam Ahmad dan Pambudi (2014:4) memberikan beberapa indikator kemudahan yaitu:

a. Produk digital fintench sangat mudah untuk dipelajari (easy to learn). Produk digital fintech atau bisa disebut saldo ovo, go-pay dan dana didindikasikan tidak sulit untuk dipelajari artinya bahwa ketika seseorang pertama kali melakukan transaksi menggunakan ovo, go-pay maupun dana, orang tersebut akan langsung mengerti dan paham tata cara penarikan uang, pengecekan saldo, ataupun transaksi lainnya dalam waktu singkat.

b. Produk digital Fintech sangat mudah untuk dioperasikan (understandable). Understandable maksudnya adalah bahwa Ovo, Go-pay dan Dana sangat mudah untuk dioperasikan. Suatu teknologi yang jelas dan dapat dioperasikan dengan mudah, maka aka memudahkan pemakai dalam penggunaannya.

c. Produk digital fintech mengerjkan dengan mudah apa yang diinginkan oleh pengguna (easy to get the system to do what user want to do). Easy to get the system to do what user want to do bawasannya suatu Ovo, Go-Pay, dan Dana menyediakan fasilitas yang mudah dan sesuai dengan kebutuhan orang yang menggunakannya, bahkan Ovo, Go-Pay dan Dana tersebut mengerjakan apa yang seseorang inginkan dengan mudah. Tidak dibutuhkan banya usaha untuk berinteraksi dengan Produk Digital Fintech atau saldo Ovo, Go-PAY dan Dana (doesn't require a lot of mental effort)

Penggunaan produk dari grab, go-jek, dan bank ini atau disebut dengan saldo ovo, go-pay dan dana diindikasikan bahwa tidak dibutuhkan banyak usaha, maksudnya yaitu tidak banyak pengorbanan yang dilakukan ketika menggunakan teknologi.

d. Fleksibel (flexibel). Fleksibel adalah kemamouan untuk beradaptasi dan bekerja dengan efektif dalam situasi yang berbeda, dan dengan berbagai individu/kelompok. Fleksibel dalam menggunakan ovo, go-pay dan dana, diindikasikan bahwa menggunakan produk tersebut dapat dilakukan dimana saja dan dapat dilakukan kapan saja tidak terikat oleh waktu.

\section{Pengertian Kemanfaatan}

Menurut Jogiyanto (2007:114) yang dimaksud dengan manfaat yang dirasakan atau Preceived Uselfulness adalah sejauh mana seseorang percaya bahwa menggnakan suatu teknologi tertentu akan meningkatkan kinerja pekerjaannya. Sedangkan Dalcher dan Shine (2003) mendefinisikan manfaat sebagai konstruk kepercayaan seseorang bahwa penggunaan sebuah teknologi tertentu akan mampu meningkatkan kinerja mereka. Menurut Davis (1989) mendefinisikan persepsi manfaat (Perceived Usefulness) debagai "the degree to which a person believes that using particular system would enhance his or her job performance" (suatu tingkatan dimana seseorang percaya bahwa penggunaan suatu sistem tertentu akan dapat meningkatkan prestasi kerja orang tersebut).

Dari definisi diatas, diketahui bahwa manfaat yang dirasakan merupakan suatu kepercayaan tentang proses untuk pengambilan keputusan, apabila seseorang merasa percaya bahwa teknologi berguna makan mereka akan menggunakannya, sedangkan jika menurutnya teknologi itu kurang berguna maka mereka tidak akan menggunakannya. Sikap positif dalam menggunakan uang elektronik akan timbul 
karena pengguna merasa yakin bahwa uang elektronik dapat meningkaykan kinerja, produktivitas, dan keefektifan kinerja bagi pengguna.

\section{Faktor-Faktor Yang Memepengaruhi Kemanfaatan}

Dari aspek kemanfaatan penggunaan (Perceived Usefulness), faktor yang membentuknya terdiri dari faktor intern dan ekstern perusahaan. Igbaria (1995) mengembangkan model teoritis aspek perilaku terhadap teknologi informasi yang menyebutkan bahwa faktor-faktor yang mempengaruhi perceived usefulness meliputi:

1. Kemudahan penggunaan (ease of use). Merupakan ukuran atau tingkatan dimana seseorang percaya bahwa sistem informasi atau produk digital fintech dapat mudah dipahami dan digunakan.

2. Dukungan pengetahuan internal (internal support). Merapakan dukungan pengetahuan teknis yang dimiliki secara individual maupun kelompok mengenai pengetahuan teknologi informasi.

3. Pelatihan internal (internal training). Merupakan sejumlah pelatihan yang sudah pernah diperoleh pengguna (user) dari pengguna lainnya (other user) atau dari spesialisasi tentang digital fintech yang ada di dalam organisasi.

4. Dukungan manajemen (management support). Merupakan tingkat dukungan secara umum yang diberikan manajemen puncak dalam organisasi.

5. Dukungan eksternal (external support). Merupakan dukungan pengetahuan teknis dari pihak luar yang dimiliki secara individual maupun kelompok mengetahui pengetahuan tentang teknologi informasi.

6. Pelatihan eksternal (external training). Merupakan sejumlah pelatihan yang sudah pernah diperoleh pengguna (user) atau spesialisasi tentang digital fintecg dari pihak luar.

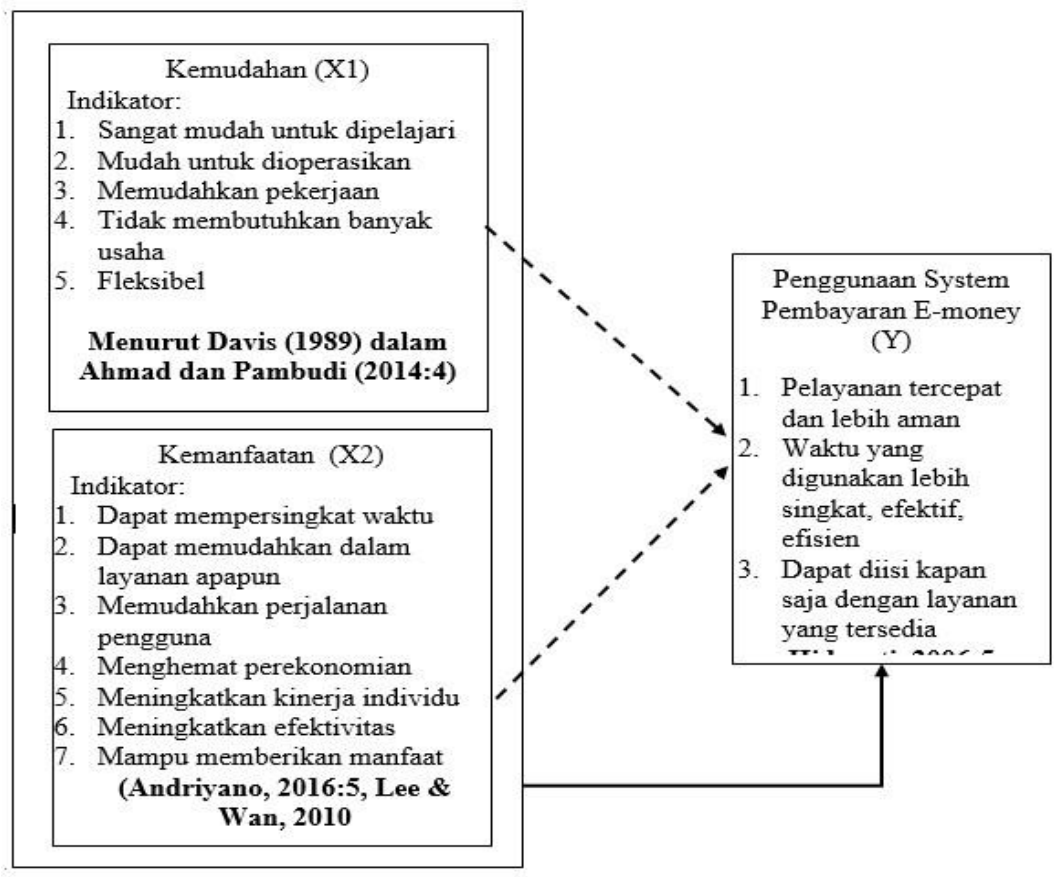

Gambar 1. Kerangka Penelitian 
Hipotesis penelitian ini adalah:

\section{Indikator Kemanfaatan}

(Lee \& Wan, 2010) menjelaskan beberapa indikator kemanfaatan (Perceived usefulnees) meliputi: (a) Menggunakan produk grab (ovo), prodk go-jek (go-pay) dan produk Bank (Dana) dapat mempersingkat waktu pengguna dalam masalah layanan apapun; (b) Menggunakan produk grab (ovo), prodk go-jek (go-pay) dan produk Bank (Dana) dapat memudahkan pengguna dalam masalah layanan apapun; dan (c) Produk uang elektronik ovo, go-pay dan dana dapat memudahkan perjalanan pengguna, dan menghemat perekonomian bagi pengguna.

Ha 1 Terdapat Pengaruh Secara Parsial Kemudahan Terhadap Sistem Pembayaran Elektronik Oleh Pengguna Ovo, Go-Pay Dan Dana Pada Mahasiswa Manajemen Di Universitas Tribhuwana Tunggadewi Malang

Ha 2 Terdapat Pengaruh Secara Parsial Kemanfaatan Terhadap Sistem Pembayaran Elektronik Oleh Pengguna Ovo, Go-Pay Dan Dana Pada Mahasiswa Manajemen Di Universitas Tribhuwana Tunggadewi Malang

Ha 3 Terdapat Pengaruh Secara Simultan Kemudahan dan Kemanfaatan Terhadap Sistem Pembayaran Elektronik Oleh Pengguna Ovo, Go-Pay Dan Dana Pada Mahasiswa Manajemen Di Universitas Tribhuwana Tunggadewi Malang

\section{METODE PENELITIAN}

Jenis penelitian yang digunakan pada penelitia ini yaitu menggunakan penelitian deskriptif kuantitatif yang menekankan pada pengujian teori-teori melalui pengukuran variabel-variabel penelitian dengan angka dan melakukan analisis data dengan prosedur statistik. Di dalam penelitian ini yang menjadi populasi adalah mahasiswa manajemen yang menggunakan e-money aplikasi Grab (ovo) dan Go-Jek (Go-Pay) dan Kartu Elektronik atau (dana) pada kampus Universitas Tribhuwana Tunggadewi Malang, dan jumlah populasi ini sudah diketahui karena mahasiswa aktif manajemen telah terhitung yaitu 900 mahasiswa aktif manajemen semua angkatan. Penentuan sampel menggunakan rumus finite population, sehingga diketahui jumlah samel adalah 90. Dalam penelitian ini teknik pengambilan sampelnya yaitu menggunakan rentidental sampling, pengambilan sampel dengan rentidental sampling adalah teknik yang didasarkan dengan pertimbangan tertentu sesuai dengan karakteristik tujuan dari penelitian untuk menghasilkan data yang lebih representatif (Sugiyono, 2010). Karakteristik khusus yang diginakan dalam penelitian ini yaitu mahasiswa manajemen pengguna aplikasi Grab, Gojek dan Dana tau kartu kredit dan kartu debet, responden sudah pernah merasakan kemudahan dan kemanfaatan dari system pembayaran elektronik Ovo, Go-Pay dan Danadalam layanan apapun minimal 3 kali pemakain, Responden harus sudah pernah melakukan transaksi pembayaran elektronik menggunakan saldo ovo, go-pay, dan dana minimal 3 kali transaksi pembayaran. Variabel yang digunakan dalam penelitian ini adalah Kemudahan (X1), Kemanfaatan (X2) dan Pemggunaan Sistem Pembayaran Elektronik Money (Y) yang definisi operasionalnya adalah sebagai berikut: 
Tabel 1. Variabel, Definisi Operasional, dan Indikator.

\begin{tabular}{|c|c|c|}
\hline Variabel & Definisi Operasional & Indikator \\
\hline $\begin{array}{l}\text { Kemudahan } \\
\text { (X1) }\end{array}$ & $\begin{array}{l}\text { Kemudahan adalah tingkatan } \\
\text { dimana seseorang percaya bahwa } \\
\text { suatu system teknologi tertentu } \\
\text { akan bebas dari suatu usaha dan } \\
\text { teknologi tersebut mudah untuk } \\
\text { dipahami }\end{array}$ & $\begin{array}{l}\text { 1. Sangat mudah untuk dipelajari } \\
\text { 2. Mudah untuk dioperasikan } \\
\text { 3. Memudahkan pekerjaan } \\
\text { 4. Tidak membutuhkan banyak usaha } \\
\text { 5. Fleksibel }\end{array}$ \\
\hline $\begin{array}{l}\text { Kemanfaatan } \\
\text { (X2) }\end{array}$ & $\begin{array}{l}\text { Kemanfaatan adalah suatu } \\
\text { kepercayaan tentang proses } \\
\text { pengambilan keputusan, dimana } \\
\text { seseorang percaya bahwa } \\
\text { menggunakan suatu teknologi } \\
\text { tertentu akan meningkatkan kinerjs } \\
\text { pekerjaannya. }\end{array}$ & $\begin{array}{l}\text { 1. Dapat mempersingkat waktu } \\
\text { 2. Dapat memudahkan dalam layanan } \\
\text { apapun } \\
\text { 3. Memudahkan perjalanan pengguna } \\
\text { 4. Menghemat perekonomian } \\
\text { 5. Meningkatkan kinerja individu } \\
\text { 6. Meningkatkan efektivitas } \\
\text { 7. Mampu memberikan manfaat }\end{array}$ \\
\hline $\begin{array}{l}\text { Penggunaan } \\
\text { Sistem } \\
\text { Pembayaran } \\
\text { Elektronik } \\
\text { Money (Y) }\end{array}$ & $\begin{array}{l}\text { Sistem pembayaran adalah sistem } \\
\text { yang mencakup seperangkat aturan, } \\
\text { lembaga dan mekanisme yang } \\
\text { digunakan untuk melaksanakan } \\
\text { pemindahan dan guna memenuhi } \\
\text { suatu kewajiban yang timbul dari } \\
\text { suatu kegiatan ekonomi }\end{array}$ & $\begin{array}{l}\text { 1. Pelayanan tercepat dan lebih aman } \\
\text { 2. Waktu yang digunakan lebih singkat, } \\
\text { efektif, efisien } \\
\text { 3. Dapat diisi kapan saja dengan layanan } \\
\text { yang tersedia lainnya }\end{array}$ \\
\hline
\end{tabular}

Sumber: Data diolah 2020

Metode analisis data pada penelitian ini menggunakan analisis pendekatan kuantitatif, yaitu dengan suatu perhitungan yang relevan terhadap masalah yang diteliti. Adapun alat analisis yang digunakan yaitu metode analisis deskriptif, regresi berganda. Analisis Regresi Berganda ini digunakan untuk mengetahui apakah Pengaruh Kemudahan dan Kemanfaatan Terhadap Sistem Pembayaran Elektronik Money. Pada analisis Regresi berganda dilakukan langkah rumus sebagai berikut (Suharyadi dan Purwanto, 2004:509).

\section{PEMBAHASAN}

Perkembangan dunia digital yang didukung oleh berkembangnya gadget atau smartphone telah meruabah beberpa aspekkehidupanmasyarakatan , termasuk fleksibelitas dalam hal pembayaran. Kemunculan E-Money atau pembayaran elektronik tidak bisa dipungkiri telah membawa peruabahn cukup signifikan dalam kehidupan Sebagian besar masyarakat. Hal tersebut juga telah mampu membangun ekosistem terbuka yang memungkinkan siapapun yang mau bergabung itu bisa. Didalam ekosistem tersebut, menyediakan platform pembayaran melalui cara-cara online. Ekosistem yang dibuat juga sangat fleksibel untuk mengatasi kendala soal payment di Indonesia. Adanya penggabungan antara kebutuhan pembayaran, perkembangan digital di Indonesia yang semakin berkembang, serta tingginya penetrasi pengguna smartphone 
di Indonesia telah menjadi pemicu munculnya platform-platform E-Money seperti OVO, DANA dan GO-PAY.

Tabel 2. Analisis Regresi Berganda

\begin{tabular}{lcc}
\hline Variabel bebas & Koefisiensi Regresi & Konstanta \\
\hline Kemudahan (X1) & 0,179 & 2,406 \\
Kemanfaatan (X2) & 0,586 & \\
\hline
\end{tabular}

Sumber: Data primer diolah 2020

Berdasarkan hasil dari penelitian maka dapat kita ketahui bahwa variabel kemudahan dan kemanfaatan terhadap sistem pembayaran elektronik money rata-rata mempunyai korelasi > $\mathrm{r}$ tabel dimana ini menunjukkan bahwa tingkat ke validan data sangat akurat dan bisa menjadi acuan untuk peneliti. Sedangkan pada uji reliabilitas bisa diukur tingkat kepercayaanya atau ke absahan data yang digunakan untuk memenuhi syarat. Dimana, apabila alpha cronbach > 0,6 maka dikatakan reliabel, atau memenuhi syarat bisa dipercaya. Memuat hasil akhir analisis data bersih (bukan proses/hasil penghitungan), pengujian hipotesis, menjawab pertanyaan-pertanyaan penelitian, dan temuan-temuan. Pembahasan diarahkan pada pemaknaan hasil, pembandingan hasil dengan penelitian lain, pembandingan hasil dengan teori, dan implikasi hasil penelitian.

Tabel 3. Hasil Pengujian Hipotesis untuk Uji Parsial dengan T-Test

\begin{tabular}{lccc}
\hline Variabel Bebas & T-Hitung & Probabilitas & Keterangan \\
\hline Kemudahan (X1) & 2,227 & 0,029 & Signifikan \\
Kemanfaatan (X2) & 6,418 & 0,000 & Signifikan \\
& T Tabel = 1.662 & & \\
\hline
\end{tabular}

Sumber: Data Primer Diolah 2020

Hasil statistic uji $\mathrm{t}$ dilihat dari hasil $\mathrm{t}$ hitung variabel X1 kemudahan sebesar 2,227 sedangkan diperoleh $t$ tabel pada taraf kepercayaan 95\% (signifikan 5\% atau 0.05) dan derajat bebas $(\mathrm{df})=\mathrm{N}-\mathrm{k}=90-3=87$ dimana $\mathrm{N}=$ jumlah sampel dan $\mathrm{k}=$ jumlah variabel independen dan dependen adalah sebesar 1.662 dengan demikian $\mathrm{T}$ hitung $=$ $2,227>\mathrm{T}$ tabel $=1.662$ dan nilai signifikan sebesar 0.029 (sig < 0.05). Berdasarkan dari analisis diatas dapat dinyatakan bahwa variabel kemudahan sangat berpengaruh signifikan terhadap sistem pembayaran elektronik money dengan studi kasus pengguna Ovo, Go-pay, dan Dana pada Mahasiswa Manajemen di Universitas Tribhuwana Tunggadewi Malang. Menurut Jogiyanto (2007:115) persepsi kemudahan didefinisikan sejauh mana seseorang percaya bahwa menggunakan suatu sistem teknologi tertentu akan bebas dari suatu usaha. Sedangkan menurut Davis et al. (1989), Purwiati (2013), Sanofata (2014), Adiyanti (2015), dan Adhinagari (2018) menunjukkan bahwa persepsi kemudahan mempengaruhi secara positif dan signifikan terhadap penggunaan sistem informasi dalam menggunakan uang elektronik.

Hasil uji t selajutnya diperoleh nilai t hitung variabel X2 kemanfaatan sebesar 6,418 sedangkan diperoleh t tabel pada taraf kepercayaan 95\% (signifikan 5\% atau 0.05) dengan derajat bebas $(\mathrm{df})=\mathrm{N}-\mathrm{k}=90-3=87$ dimana $\mathrm{N}=$ jumlah sampel dan $\mathrm{k}=$ jumlah variabel independen dan dependen adalah sebesar 1.662 dengan demikian $\mathrm{T}$ hitung $=$ 
$6,418>\mathrm{T}$ tabel $=1.662$ dan nilai signifikan sebesar $0.000(\mathrm{sig}<0.005)$. Dari penelitian ini kemanfaatan menggunakan e-money yang dirasakan responden yaitu dapat menghemat perekonomian, dapat mempersingkat waktu sistem pembayaran, dapat digunakan dalam layanan apapun, kemanfaatan dari menggunakan ovo yaitu bisa untuk pemesanan transportasi, cepat dijangkau, delivery, pengiriman barang dan lain sebagainya, begitu juga dengan go-pay bisa untuk pemesanan pembelanjaan online, delivery, pengiriman barang, pemesanan transportasi, tagihan listrik dan lain-lain, sedangkan menggunakan dana bermanfaat untuk pemesanan tiket lebih cepat dan aman, pembayaran tagihan listrik dengan cepat dan lebih efektif, pengisian ulang bisa dalam jumlah besar. Berdasarkan dari analisis tersebut dapat disimpulkan bahwa variabel kemanfaatan berpengaruh signifikan terhadap sistem pembayaran elektronik money dengan studi kasus pengguna Ovo, Go-pay, dan Dana pada Mahasiswa Manajemen di Universitas Tribhuwana Tunggadewi Malang.

Tabel 4. Uji F (simultan)

\begin{tabular}{cccc}
\hline Variabel & F hitung & F tabel & Sig f \\
\hline X1 dan X2 & 45,714 & 2,48 & 0,000 \\
\hline
\end{tabular}

Sumber: Data Primer Diolah 2020

Hasil Uji signifkan simultan atau bersama-sama (uji statistik F) mengasilkan nilai $F$ hitung sebesar 45,714. Nilai $F$ tabel pada taraf kepercayaan signifikan adalah sebesar 2,48 dengan cara memandingkan $\mathrm{F}$ tabel dengan $\mathrm{F}$ hitung ( $\operatorname{sig} \mathrm{F}=0,000$ ) jadi $\mathrm{F}$ hitung $>$ F tabel $(45,714>2,48)$ yang berarti bahwa secara simultan variabel X1-X2 terhadap variabel (Y), Ho di tolak. Tetapi nilai probabilitas $<0,05$ (Sig 0,000 < 0,05). Dalam penelitian ini kemudahan dan kemanfaatan yang dirasakan responden yaitu memudahkan pemesanan baik delivery, transportasi, tagihan listrik, pemesanan tiket, belanja online ataupun sistem pembayaran secara online dan lain sebagainya, namun dilihat dari hasil penelitian bahwa variabel kemanfaatan yang lebih dominan dirasakan kenyamanannya dikarenakan kemanfaatan dari menggunakan e-money ini seorang responden sudah percaya bahwa e-money dapat memberikan manfaat yang efektif dalam melakukan sistem pembayaran secara elektronik dan tidak manual lagi.

Tabel 5. Hasil Pengujian Untuk Uji Determinasi (R square)

\section{Model Summary}

\begin{tabular}{ccccc} 
Model & R & R Square & Ajusted R Square & Std. Error of the Estimate \\
\hline 1 & 0,716 & 0,512 & 0,501 & 2,28848 \\
\hline
\end{tabular}

Sumber: Data Primer Diolah tahun 2020

Di dalam hasil penelitian tersebut dilihat bahwa hubungan antara variabel kemudahan dan kemanfaatan terhadap sistem pembayaran elektronik money dengan studi kasus pengguna Ovo, Go-pay, dan Dana pada Mahasiswa Manajemen di Universitas Tribhuwana Tunggadewi Malang, adalah sebesar $(r=0,716)$. Koefisien determinasi atau angka $\mathrm{R}$ Square adalah sebesar 0,512, kemudian Ajusted $R$ Square sebesar 0,501 dan Standar Error sebesar 2,28848. Pada Regresi linier berganda sebaiknya menggunakan $\mathrm{R}$ Square yang sudah sisesuaikan atau tertulis Adjusted $R$ Square, karena disesuaikan dengan jumlah variabel maka $\mathrm{R}$ Square yang digunakan 
adalah sebesar 0,512 hal ini berarti $0,51,2 \%$ dari variasi variabel dependen yaitu sistem pembayaran elektronik money dengan studi kasus pengguna Ovo, Go-pay, dan Dana pada Mahasiswa Manajemen di Universitas Tribhuwana Tunggadewi Malang, dapat dijelaskan oleh variabel bebas kemudan dan kemanfaatan, sedangkan sisanya 0.488 atau 48,8\% (1 - 0,512 atau $100-51,2 \%)$ dijelaskan oleh variabel-variabel lain diluar variabel yang ada yaitu variabel kepercayaan, variabel kenyamanan penggunaan, variabel minat, dan lain sebagainya.

\section{Pengaruh Kemudahan terhadap Sistem Pembayaran Elektronik Money}

Dimana pada penelitian ini dilihat dari hasil t hitung variabel X1 kemudahan sebesar 2,227 sedangkan diperoleh $\mathrm{t}$ tabel pada taraf kepercayaan 95\% (signifikan 5\% atau 0.05) dan derajat bebas (df) $=\mathrm{N}-\mathrm{k}=90-3=87$ dimana $\mathrm{N}=$ jumlah sampel dan $\mathrm{k}=$ jumlah variabel independen dan dependen adalah sebesar 1.662 dengan demikian $\mathrm{T}$ hitung $=2,227>\mathrm{T}$ tabel $=1.662$ dan nilai signifikan sebesar 0.029 (sig < 0.05). Dalam penelitian ini kemudahan yang dirasakan oleh responden dalam menggunakan produk emoney (Ovo, Go-pay, dan Dana) yaitu mudahnya untuk bertransaksi dengan produk emoney, lebih fleksibel, tidak membutuhkan banyak usaha, mudah dipelajari, dan bisa diakses dimanapun berada sehingga mahasiswa yang menggunakan produk e-money cenderung setuju bahwa e-money ini sangat memudahkan pembayaran dalam bentuk uang elektronik. Kemudahan dari produk e-money bisa digunakan untuk berbagai macam transaksi, namun dari setiap produk e-money memiliki perbedaan dan persamaan dalam bertransaksi, produk dari Ovo dan Go-pay merupakan saldo e-money yang digunakan sebagai pemesanan transportasi, pembayaran listrik, delivery, pengiriman barang dan lain sebagainya, tetapi produk Ovo dan Go-Pay ini pengisian ulang saldo atau Top-Up nya terbatas dan dalam jumalah nominal tertentu. Produk Dana ini merupakan dompet digital yang transaksinya bisa menggunkan online dan offline, dari produk ini bisa digunakan untuk pemesanan tiket, belanja online, transaksi ecomerce, top-up pulsa, pembayaran tagihan listrik dan lain sebagainya. Keunggulan dari Dana ini jumlah pengisian ulang atau top-upnya bisa dalam jumlah besar hingga 10 juta. Maka dengan ini kemudahan dari produk e-money ovo, go-pay dan dana menjadi suatu keunggulan yang dimiliki dari setiap produk dari e-money yang sudah dirasakan oleh penggunanya khususnya mahasiswa. Berdasarkan dari analisis diatas dapat dinyatakan bahwa variabel kemudahan sangat berpengaruh signifikan terhadap sistem pembayaran elektronik money dengan studi kasus pengguna Ovo, Go-pay, dan Dana pada Mahasiswa Manajemen di Universitas Tribhuwana Tunggadewi Malang. Menurut Jogiyanto (2007:115) persepsi kemudahan didefinisikan sejauh mana seseorang percaya bahwa menggunakan suatu sistem teknologi tertentu akan bebas dari suatu usaha. Sedangkan menurut Davis et al. (1989), Purwiati (2013), Sanofata (2014), Adiyanti (2015), dan Adhinagari (2018) menunjukkan bahwa persepsi kemudahan mempengaruhi secara positif dan signifikan terhadap penggunaan sistem informasi dalam menggunakan uang elektronik.

\section{Pengaruh Kemanfaatan terhadap Sistem Pembayaran Elektronik money}

Berdasarkan pada hasil penelitian ini yang dilakukan dengan menggunakan ttest, diperoleh nilai $\mathrm{t}$ hitung variabel X2 kemanfaatan sebesar 6,418 sedangkan diperoleh t tabel pada taraf kepercayaan 95\% (signifikan 5\% atau 0.05) dengan derajat 
bebas $(\mathrm{df})=\mathrm{N}-\mathrm{k}=90-3=87$ dimana $\mathrm{N}=$ jumlah sampel dan $\mathrm{k}=$ jumlah variabel independen dan dependen adalah sebesar 1.662 dengan demikian $\mathrm{T}$ hitung $=6,418>\mathrm{T}$ tabel $=1.662$ dan nilai signifikan sebesar 0.000 ( $\mathrm{sig}<0.005$ ). Kemanfaatan merupakan suatu kepercayaan tentang proses pengambilan keputusan, dimana seseorang percaya bahwa menggunakan suatu teknologi tertentu akan meningkatkan kinerja pekerjaannya. Dari penelitian ini kemanfaatan menggunakan e-money yang dirasakan responden yaitu dapat menghemat perekonomian, dapat mempersingkat waktu sistem pembayaran, dapat digunakan dalam layanan apapun, kemanfaatan dari menggunakan ovo yaitu bisa untuk pemesanan transportasi, cepat dijangkau, delivery, pengiriman barang dan lain sebagainya, begitu juga dengan go-pay bisa untuk pemesanan pembelanjaan online, delivery, pengiriman barang, pemesanan transportasi, tagihan listrik dan lain-lain, sedangkan menggunakan dana bermanfaat untuk pemesanan tiket lebih cepat dan aman, pembayaran tagihan listrik dengan cepat dan lebih efektif, pengisian ulang bisa dalam jumlah besar. Kemanfaatan ini yang lebih banyak dirasakan oleh responden karena pengguna e-money (ovo, go-pay dan dana) sudah percaya dan mengetahui manfaat dari e-money dan lebih dari 3 kali penggunaan dan sudah percaya dengan kemanfaatan emoney ini. Berdasarkan dari analisis tersebut dapat disimpulkan bahwa variabel kemanfaatan berpengaruh signifikan terhadap sistem pembayaran elektronik money dengan studi kasus pengguna Ovo, Go-pay, dan Dana pada Mahasiswa Manajemen di Universitas Tribhuwana Tunggadewi Malang. Menurut Davis et al. (1989), Purwiati (2013), Sanofata (2014), Adiyanti (2015), dan Adhinagari (2018) menyatakan bahwa persepsi manfaat mempengaruhi secara positif dan signifikan terhadap penggunaan sistem informasi dalam menggunakan uang elektronik. Sedangkan menurut Dalcher dan Shine (2003) menyatakan bahwa persepsi kemanfaatan sebagai kepercayaan seseorang dalam penggunaan sebuah teknologi akan mampu meningkatkan kinerja untuk memperoleh kemanfaatan dalam menggunakan uang elektronik.

\section{Pengaruh Kemudahan, Kemanfaatan terhadap Sistem Pembayaran Elektronik Money}

Di dalam penelitian ini pengaruh kemudahan dan kemanfaatan terhadap sistem pembayaran elektronik money sangat berpengaruh, terdapat perbedaan dengan pengujian secara parsial dan secara simultan dengan hasil Uji signifkan simultan atau bersama-sama (uji statistik F) mengasilkan nilai F hitung sebesar 45,714. Nilai F tabel pada taraf kepercayaan signifikan adalah sebesar 2,48 dengan cara memandingkan $\mathrm{F}$ tabel dengan $F$ hitung ( $\operatorname{sig} F=0,000)$ jadi $F$ hitung $>F$ tabel $(45,714>2,48)$ yang berarti bahwa secara simultan variabel X1-X2 terhadap variabel (Y), Ho di tolak. Tetapi nilai probabilitas $<0,05$ (Sig 0,000 < 0,05). Dalam penelitian ini kemudahan dan kemanfaatan yang dirasakan responden yaitu memudahkan pemesanan baik delivery, transportasi, tagihan listrik, pemesanan tiket, belanja online ataupun sistem pembayaran secara online dan lain sebagainya, namun dilihat dari hasil penelitian bahwa variabel kemanfaatan yang lebih dominan dirasakan kenyamanannya dikarenakan kemanfaatan dari menggunakan e-money ini seorang responden sudah percaya bahwa e-money dapat memberikan manfaat yang efektif dalam melakukan sistem pembayaran secara elektronik dan tidak manual lagi. Responden percaya bahwa e-money ini akan memudahkan dalam setiap layanan dan mempersingkat waktu serta membantu meringankan beban untuk pembayaran penagihan, pembelanjaan, yang lebih fleksibel 
dalam penggunaannya. Adhinagari dan Listiani (2018) menyatakan bahwa persepsi manfaat dan persepsi kemudahan penggunaan berpengaruh sacara positif dan signifikan terhadap penggunaan uang elektronik sehingga dapat mempengaruhi minat seseorang dalam menggunakan uang elektronik.

\section{SIMPULAN DAN SARAN}

\section{Simpulan}

1. Kondisi elektronik money saat ini lebih banyak digunakan dari pada pembayaran manual, kemudahan dan kemanfaatan uang elektronik memberikan kenyamanan pengguna dari setiap transaksinya khususnya mahasiswa.

2. Secara parsial variabel kemudahan berpengaruh signifikan terhadap sistem pembayaran elektronik money dengan studi kasus pengguna Ovo, Go-pay, dan Dana pada Mahasiswa Manajemen di Universitas Tribhuwana Tunggadewi Malang. Secara parsial variabel kemanfaatan berpengaruh signifikan terhadap sistem pembayaran elektronik money dengan studi kasus pengguna Ovo, Gopay, dan Dana pada Mahasiswa Manajemen di Universitas Tribhuwana Tunggadewi Malang.

3. Secara simultan variabel kemudahan dan kemanfaatan berpenfaruh signifikan terhadap sistem pembayaran elektronik money dengan studi kasus pengguna Ovo, Go-pay, dan Dana pada mahasiswa manajemen di Universitas Tribhuwana Tunggadewi Malang.

\section{Saran}

1. Kemudahan pada sistem pembayaran tetap terus digunakan dan ditingkatkan dari layanan, orderan, dan produk lainnya agar meminimalisisir beban perekonomian sehari-sehari dan memberikan kenyamanan pada mahasiswa sendiri.

2. Lebih menyukai dan menggunakan dari kemanfaatan sistem digital fintech dan produk-produk dari sistem pembayaran elektronik karena akan memudahkan den lebih menyingkat waktu tanpa harus berusaha yang akan membebani perekonomian sehari-hari.

3. Untuk mencoba menggunakan, karena zaman semakin modern dan lebih cepat dalam perkembangannya, agar mengurangi pembayaran manual dan memperlambat transaksi.

4. Bagi peneliti selanjutnya diusahkan dalam melakukan penelitian yang sama mengenai uang elektronik atau sejenisnya dengan penelitian ini maka diupayakan untuk lebih spesifik dan luas lagi penelitiannya. Agar hasil dari penelitiannya lebih maksimal dan bisa digunakan untuk tambahan wawasan dan informasi peneliti selanjutnya.

\section{DAFTAR PUSTAKA}

Adhinagari, A. H (2018). Pengaruh Persepsi Manfaat, Persepsi Kemudahan, Kepercayaan dan Persepsi Resiko Terhadap Persepsi Penggunaan E-money. Yogyakarta: Universitas Islam Indonesia. 
Adiyanti, A. I (2015). Pengaruh Pendapatan, Manfaat, Kemudahan Penggunaan Daya Tarik Promosi, dan Kepercayaan Terhadap Minat Menggunakan Layanan EMoney. (Studi Kasus: Mahasiswa Universitas Brawijaya). Jurnal. Ilmiah Mahasiswa Fakultas Ekonomi dan Bisnis Universitas Brawijaya. 3 (1).

Akdon Ridwan. 2007. Rumus dan Data dalam Analisis Statistika. Bandung: Alfabeta.

Andriyano, Y. 2016. Pengaruh Persepsi Kemudahan, Persepsi Kebermanfaatan, Persepsi Risiko dan Kepercayaan Terhadap Minat Menggunakan Rekening Ponsel (Studi Kasus Pada Nasabah CIMB Niaga Daerah Istimewa Yogyakarta). Jurnal. Yogyakarta: Fakultas Ekonomi Universitas Negeri Yogyakarta

Arikunto, S. 2010. Prosedur Penelitian Suatu Pendekatan Praktik. Jakarta: PT. Rineka Cipta.

Bhaskoro. A.J. 2013. Survey:Orang Indonesia Saat ini Familiar Dengan E-money Namun Masih enggan Untuk Menggunakannya. https://dailysocial.id/ post/survey-emoney-indotelkom Diakses pada 20 September 2019.

Dalcher, I., \& Shine, J. (2003). Extending the New Technology Acceptance Model to Measure the End User Information Systems Satisfaction in a Mandatory Environment: A Bank's Treasury. Technology Analysis \& Strategic Management, 15 (4), 441-455

Davis, F. D., Bagozzi, R. P., \& Warshaw, P. R. (1989). User Acceptance of Computer Technology: A Comparison of Two Theoretical Models. Management Science, 35 (8), 982-1003.

Ghozali, Imam. 2011. Aplikasi Analisis Multivarite dengan Program SPSS. Semarang: Badan Penerbit Universitas Diponegoro.

Hidayati, S. 2006. Operasional E-Money.Bank Indonesia.

Jogiyanto, H. M. (2007). Sistem Informasi Keperilakuan. Yogyakarta: Erlangga.

Kasmir, Dr. 2014. Bank dan Lembaga Keuangan Lainnya. Jakarta: PT Raja Grafindo Persada.

Kriyantono, Rachmat. 2006. Teknik Praktis Riset Komunikasi: Disertai Contoh Praktis Riset Media, Public Relation, Advertising, Komunikasi Pemasaran. Jakarta: Kencana.

Listianti, U. Y. (2018). Pengaruh Kepercayaan, Persepsi Kemudahan dan Persepsi Manfaat Terhadap Minat Penggunaan E-money pada Mahasiswa FEB UMS. Jurnal. Surakarta: Universitas Muhammadiyah Surakarta.

Mentari Adinda Cahya, Bandesa, M.A.D.E. Prof.Dr.I.K.G. 2018. Analisis FaktorFaktor Yang Mempengaruhi Minat Dalam Menggunakan Uang Elektronik, EJurnal Vol. 7 No. 4

Peraturan Bank Indonesia Nomor 11/12/PBI/2009 Tentang Unga Elektronik (Electronic Money) Lembaran Negara Republik Indonesia Tahun 2009 Nomor 65, Tambahan Lembaran Negara Republik Indonesia Nomor 5001).

Peraturan Bank Indonesia Nomor 16/9/PBI/2014 Tentang Perubahan Atas Peraturan Bank Indonesia Nomor 11/12/PBI/2009 Tentang Uang Elektronik (Electronic Money) (Lembaran Negara Republik Indonesia Tahun 2014 Nomor 69, Tambahan Lembaran Negara Republik Indonesia Nomor 5524).

Pratama Andhika Bayu dan Dharma Suputa I Dewa Gede, 2019. Pengaruh Persepsi Manfaat, Persepsi Kemudahan Pengguaan, dan Tingkat Kepercayaan Pada Minat Menggunakan Uang Elektronik, E-Jurnal Vol. 27 No. 2 
Purwiati, E. (2013). Faktor-faktor yang Mempengaruhi Adopsi E-money. Tesis. Yogyakarta: Universitas Gadjah Mada.

Sanofata, D. (2014). Analisis Faktor-faktor Yang Mempengaruhi Intensi Penggunaan Electronic Money. Yogyakarta: Universitas Gadjah Mada.

Sugiyono. 2016. Metode Penelitian Kuantitatif Kualitatif \& R\&D. Bandung: Alfabeta

Suharyadi Purwanto. 2004. Statistika untuk Ekonomi dan Keuangan Modern. Penerbit Salemba Empat. Jakarta.

Tazkiyyaturrohmah, Rifqy. 2018. Eksistensi Uang Elektronik Sebagai Alat Transaksi Keuangan Modern, Yuridika, Vol. 3 No. 1

Usman, Rachmadi. 2017. Karekteristik Uang Elektronik Dalam Sistem Pembayaran, Referensi, Vol. 32 No. 1

Wiersma, William. 1986. Metode Penelitian Kuantitatif Kualitatif \& R\&D. Bandung: Alfabeta 